\title{
Lars Sandbeck
}

Afsked med almagten. Et bidrag til det kristne gudsbillede. Anis 2014. 134 sider. Pris: $179,00 \mathrm{kr}$.

Lars Sandbeck leverer med sin bog Afsked med almagten et bidrag i en debat, der efterhånden i nogle år har verseret i den folkekirkelige offentlighed. Det er denne diskussion, som den programmatiske titel har i sigte. Bogens indledende sider beskriver situationen: Den akademiske teologi har i vid udstrækning kritiseret almagtsforestillingen. Men der høres fortsat "stemmer fra fortiden" i form af teologer og præster, som betragter almagtsforestillingen (eller almagtstroen, for 'tro' og 'forestilling' bruges flere steder i bogen i flæng) som uopgivelig del af kristendommen (11-12). Stillet over for den selvfølgelighed, hvormed almagtstanken opfattes i dele af debatten, ser LS sig her foranlediget til en kritisk begrebsafklaring, hvilket han i bogen foretager i et letforståeligt sprog, en veloplagt tone og en causerende, essayistisk stil, som gør bogen meget velegnet som indspil i en diskussion med et bredt felt af interesserede.

Sandbecks sigte er imidlertid dobbelt (14-15): Han vil for det første idet han tager tråden op fra de sidste par århundreders teismekritik - "afvæbne det synspunkt, at benægtelsen af Guds almagt skulle stride imod den kristne tro". Men han vil også positivt formulere, hvad man i kristen forstand kan forstå ved Guds magt. Argumentationen forløber følgelig, med en umiddelbart indlysende konsekvens, i fire skridt: I indledningen (1) tager han tråden op fra den aktuelle debat, og den begrebslige bane kridtes op. Dernæst følger i to store midterafsnit den kritiske og polemiske indsats i form af dels en længere begrebshistorisk betragtning (2), dels en egentlig begrebskritik (3) og til slut den positive overvejelse (4).

Væsentlig for hele bogens argumentation er indledningens præcisering: Opgøret gælder særlig to af traditionens opfattelser af almagten: For det første den opfattelse, som Sandbeck kalder den 'modale', nemlig det senskolastiske begreb om Guds potentia absoluta - tanken om at Gud kan alt, dvs. alt muligt, og ikke bare alt virkeligt (med en klassisk aforisme kan han dermed også skabe en sten, han ikke kan løfte). Og for det andet tanken om Gud som transcendent kausalitet: alt, hvad der sker, er bevirket af Gud-hermed er der i sidste ende tale om determinisme. Disse er i fokus for opgøret, fordi de iflg. LS er de mest udbredte i traditionen og den folkelige bevidsthed (15), selv om de altså ikke har været gangbar teologisk mønt i adskillige århundreder.

Sandbeck undlader ikke at nævne, at der er gjort teologiske forsøg på at omtyde almagtsbegrebet (herunder hører blandt andet selvbegrænsningstolkninger og begreber om 'kærlighedens almagt'), som også indebærer opgør med disse to opfattelser. Men han vælger her af formidlingshensyn - af "trang til at undgå unødig forvirring og misforståelser" (17) - at vægte entydigheden. Dette kunne i parentes bemærket foranledige til at overveje, 
hvad pointen kunne være med ikke at skrotte almagtsbegrebet fuldstændig, men at bibeholde det som afsæt for en kritisk tydning og omtydning. Det er imidlertid Sandbecks polemiske pointe, at almagtsbegrebet uundgåeligt ender i én af de to varianter, og derfor står almagtsbegrebet som sådan for skud. Formidlingshensynet glider utematisk over i en egentlig identifikation af 'almagt' med enten determinisme eller potentia absoluta-tanke, en identifikation, som kommer til at stå som præmis for den videre argumentation.

På den baggrund udfolder LS begrebets historie i en redegørelse (19-57), hvor han trækker på litteraturen på området og her forfægter, at hverken det hebraiske 'shaddai' eller det græske 'pantokrator', men først det latinske 'omnipotentia' svarer til almagtsbegrebet, hvorved Bibelen holdes fri, og den latinske tænkning bliver skurken. Dog var de latinske teologer fra Augustin til Thomas Aquinas optaget af grænserne for almagten, så at først senmiddelalderens interesse for Guds væsensegenskaber giver grobund for spekulationer over almagtens implikationer. Det er her Sandbecks pointe, at tanken om Guds 'al-kunnen' (potentia absoluta) fører sig selv ad absurdum og i sidste instans ender i benægtelsen af enten Guds eller verdens eksistens. Pointeret taler LS om "almagtsekstremisme": Der er hermed tale om en forestillingen iboende tendens til, trods oprindeligt gode intentioner om at garantere et grundlag for tilliden til Gud, at slå om i sin modsætning og underminere den tillid til Gud, som evangeliet havde etableret (50f.).

LS fortsætter med en mere aktualiserende begrebskritik i 3. kapitel, "Almagtens problemer" (59-102). Med udgangspunkt i en kritik af selvbegrænsningstolkninger for ikke at tænke almagten konsekvent nok, fremhæver han problemer og paradokser ved almagtsbegrebet. Det er her karakteristisk, at han kritiserer almagtsbegrebet som selvstændig størrelse, dets konsekvenser og iboende logik, isoleret fra de mulige sproglige sammenhænge det indgår i og spiller sammen med. Dette i modsætning til magtbegrebet som sådan (uden ' al-') i det afsluttende kapitel (103-129), hvor LS fremlægger et positivt bud på en kristologisk bestemt gudsforståelse, hvor kærlighedstanken bliver afgørende for, hvordan man kan tale om Guds magt. Kritisk vendt mod en determinerende, vilkårlig eller tyrannisk magt omtydes 'Guds magt' som en udholdende, frigørende, tilgivende og livsfornyende magt.

Den egentlige afsked vedrører altså ikke magtbegrebet som sådan, men derimod netop forstavelsen 'al-' (jf. 113), som afkodes for problematiske implikationer, båret af argumentationens præmis - dvs. den identifikation, LS fra begyndelsen har foretaget af almagten med de to nævnte former, determinisme og al-kunnen (potentia absoluta). Polemisk har denne strategi til følge, at selvom nutidige fortalere for et (teologisk kvalificeret og modificeret) almagtsbegreb næppe abonnerer på hverken determinisme eller potentia absoluta, kan de klandres for disse konsekvenser: "Hvis vi hævder, Gud er almægtig, har vi grundlæggende at gøre med en anden Gud, end hvis vi hævder, Gud ikke er almægtig", hedder det (62). 
Det er for så vidt konsekvent, men præmissen har et vilkårligt præg. De afsluttende positive overvejelser over magtbegrebet formuleres implicit og eksplicit i totalitetskategorier ( $\mathrm{fx}$ med udsagnet "Guds magt er magten til at udholde alt for vores skyld” (88, jf. også 109) og med udlægningen af missionsbefalingen og af Matt 19,26 (115ff.)), og det er vel nærmest heller ikke til at undgå, for så vidt som gudstanken (hvad enten den er baseret på kristologi eller religiøs erfaring) indeholder totalitets- og universalitetsdimensioner. Med andre ord er også forstavelsen 'al-' åben for forskellige tydninger.

\section{Christine Svinth-Varge Pöder}

\section{Kajsa Brilkman}

Undersåten som förstod. Den svenska reformatoriska samtalsordningen och den tidigmoderna integrationsprocessen. Skellefteå: Artos \& Norma Bokförlag 2013. 270 s. SEK 347.

Historikeren Kajsa Brilkmans ph.d.-afhandling er en undersøgelse af den tidlige svenske reformation, der bestemmes som perioden mellem de første Lutheroversættelser fra 1520'ernes begyndelse til rigsdagen i Västerås 1544. Brilkmans greb om reformationen bestemmes dog ikke af disse ydre omstændigheder, men af den reformatoriske diskurs og reguleringen af denne, som den fremgår af et omfangsrigt kildemateriale. Fremstillingen, der er skrevet i et forbilledligt klart sprog, præges af stor indsigt og kritisk korrektion af tidligere forskning. Bogen falder i 5 hoveddele: Kapitel 1 (11-46) præsenterer de forskningshistoriske, teoretiske og metodiske forudsætninger, og kapitel 2 (47-98) udfolder og eksemplificerer den diskursteoretiske metode, som Brilkman betjener sig af. De følgende empiriske kapitler analyserer reformationsdiskursen i politiske og teologiske kilder: Kapitel 3 (99142) er viet husstanden og menigheden, kapitel 4 (143-188) det nationale fællesskab, og endelig kapitel 5 (189-220) fællesskabets eksklusionsmekanismer i konstruktionen af det fremmede.

Forfatteren påpeger selv, at det at "beskriva reformationen som ett sätt att tale leder in i ett för reformationsforskningen sällan använt sätt att läsa källorna” (21). Megen forskning har villet forstå reformationens tekster og centrale udsagn som refleksioner af det, der skete - hvilket kort sagt betyder, at det er aktørerne, der skaber diskursen. Brilkman fastholder imidlertid på foucaultsk vis, at ingen ejer sproget: Diskursen skaber aktørerne. Det forekommer måske ikke videre originalt, men Brilkman viser i sin diskussion med den tidligere reformationsforskning, der fremstår tydeligst $\mathrm{i}$ afhandlingens konklusion (221-240), at det har vidtrækkende konsekvenser for forståelsen af reformationen. I kapitel 2 gennemgås det begrebsnetværk, der diskursivt strukturerer reformation, nemlig sandhed, at forstå, hjerte, sjel, kristeligt. Med disse begreber blev tilegnelse og anvendelse af viden diskursens centrale tema og rettesnor for dens subjekter. Den egentlige metode 